\title{
SOLID WASTE MANAGEMENT PRACTICES IN SELECTED FOOD SERVICE ESTABLISHMENTS IN TALISAY CITY, NEGROS ISLAND REGION, PHILIPPINES
}

\author{
Ricky B. Acanto \\ School of Arts and Sciences, Carlos Hilado Memorial State College, Talisay City, Negros Occidental, Philippines \\ acantoricky@gmail.com,ricky_acanto@yahoo.com
}

\begin{abstract}
This study aimed to determine the solid waste management practices in selected food service establishments in the Talisay City, Negros Island Region, Philippines. The study used the descriptive method of research and purposive sampling technique. The respondents of the study were 180 owners/food sellers of bakery, eatery, food carts, mobile vendors, market vendors and sari-sari stores as the solid wastes generators. Frequency and percentage were used to analyze the data gathered. Food wastes and plastics topped among the solid waste generated by the food service establishments. Plastic bags were the primary waste storage among the respondents; closed and open containers were also utilized. The food service establishments were dependent to the City government for their solid waste disposal. Solid waste generators dumped their waste in the designated areas for collection. It is worth noting that none of the respondents practice burning of garbage but few are dumping their garbage anywhere. None of the respondents practiced solid waste segregation and 3Rs. Proof established that Republic Act 9003 or Solid Waste management Act of 2000 is not fully implement in the City of Talisay.
\end{abstract}

Keywords: Solid Waste, Waste Management, Disposal Practices, Recycling, Republic Act 9003. $* * *$

\section{INTRODUCTION}

Increasing global population and growing demand for food have its advantages in the environment -a rise in the amount of solid waste being generated by individual. The industrialized society today also creating and developing throw away products that become mountains of garbage. The problem exists not only in the urban areas where population density is high and human activities such as production of different types of wastes are continuous and intensive but also prevalent rural community. According to healthepic.com [23], garbage are the breeding grounds for disease-carrying vectors, like cockroaches, flies, mosquitoes and rats. Additionally, about 8,000, 000 flies are produced in one cubic meter of garbage, which carry pathogenic microorganisms and causes disease to humans.

A large volume of garbage and waste materials from homes, hospitals, offices and market places as seen in television and observed in the locality have littered the streets and become an eye sore to the public, clogged canals and drainage systems and caused the air to become foul smelling which become detrimental to humans health.

Solid waste management is becoming a major public health and environmental concern in urban areas of the country. In Metro Manila alone, the amount of garbage produce per capita daily is about $0.5 \mathrm{~kg}$ according to the study conducted by Environmental Management Bureau [20]. Additionally, about $73 \%$ of the 5,250 metric tons of waste generated daily are collected by dump trucks hired by the respective local government units. The remaining $27 \%$ of the daily waste or about 1,417.5 metric tons end up in canals, vacant spaces, street corners, market places, rivers and other places.

In the country, solid waste management is given a low priority which result to a very limited funds for the solid waste management implementer in the local government unit.

Considering that the food establishments generated different types of solid waste, they must also comply with the RA 9003 implemented by the Local Government Unit. Improvement of environmental sanitation is therefore, crucial and imperative to prevention of disease and promotion of public health. Upgrading of sanitary practices is everyone's concern as everyone generates garbage; everyone can be a part of the problem. As part of the problem, everyone can also be a part of the solution.

To address solution of the solid waste problem, the government enacted the Republic Act No. 9003 otherwise known as the Ecological Solid Waste Management Act of 2000 and Republic Act 7160 otherwise known as DENR AO No. 98-49 Series of 1998 which mandates the devolution to the Local Government Unit the responsibility to provide basic services, such as but not limited to general hygiene and sanitation; beautification and solid waste management. In addition, Republic Act No. 9003 provides the legal framework for the country's systematic, comprehensive and ecological solid waste management program that shall ensure protection of public health and the environment. It 
underscores, among other things, the need to create the necessary institutional mechanisms and incentives, as well as imposes penalties for acts in violation of any of its provisions according to Environmental Management Bureau, Philippines [20].

Some of the salient features of RA 9003 are the promotion of research on solid waste management and environmental education in the formal and non-formal sectors; and the LGU's shall be primarily responsible for the implementation and enforcement of the provisions of this Act within their jurisdiction. Moreover, segregation and collection of the solid waste shall be conducted at the barangay level specifically for biodegradable, compostable and reusable wastes provided that the collection of non-recyclable materials and special wastes shall be the responsibility of the municipality.

The City of Talisay, Negros Occidental has existing solid waste management program through the Clean and Green program. Material recovery facilities are also observed in some barangays. Despite the effort of the City government to implement the solid waste management program, levels of wastes dumped in non-designated areas for collection as well as in the streets were visible. It is in this premise that the researcher wish to verify solid waste management practices among food service establishments in the City of Talisay, Negros Occidental, Negros Island Region, Philippines.

\subsection{Statement of the Problem}

Generally, the study aimed to determine the solid waste management practices in selected food establishments in Talisay City, Negros Occidental, Negros Island Region, Philippines.

Specifically, it aimed to answer the following questions:

1. What are the types of solid waste generated among food establishments?

2. What are the solid wastes storage practices among food establishments?

3. What are the solid waste management disposal practices adopted by food establishments?

\subsection{Conceptual Framework}

This study aimed to determine the solid waste management practices among selected food service establishments in the City of Talisay, Negros Occidental.

The different sources of solid waste from industrial sectors specifically in the food establishments includes vegetable stalk and peelings, rotted fruits and vegetables, plastics, packaging materials (carton, paper), fish scales, gills \& bones, cans, and bottles. The types of solid waste generated by the food establishments' owners and workers are categorized into degradable and non-degradable. The solid waste management disposal practices adopted by the food establishments are classified into composting, recycling, reusing, and other methods namely selling to junkshop, open fit, dependent on Local Government Unit waste collector.
Independent Variables Dependent Variables

\begin{tabular}{|c|}
\begin{tabular}{|l|} 
I. Types of Solid \\
Waste Generated \\
II. Solid Waste \\
Management \\
Storage Practices \\
III. Solid Waste \\
Management \\
Disposal Practices
\end{tabular} \\
\hline \\
Solid Waste \\
Management \\
Practices in \\
Selected Food \\
Establishments
\end{tabular}

Figure -1: Shows the Schematic Diagram of the study.

\section{METHODOLOGY}

\subsection{Respondents of the Study}

The respondents of the study were 180 the solid waste generators in the food service establishments and classified as bakery, eatery, food carts, mobile vendors, market vendors, and sari-sari stores. They are the food sellers in the public market of Talisay City, Negros Occidental. The researcher utilized the purposive sampling technique in selecting the respondents in the study.

To assure the honesty and objectivity of the respondents in their responses, the researcher personally administered the questionnaire to the respondents. They were also assured of the anonymity of their identities. The table below shows the number of respondents in the study.

Table - 1: Respondents in the study.

\begin{tabular}{|l|l|}
\hline Respondents & f \\
\hline Bakery & 30 \\
\hline Eatery & 30 \\
\hline Food Carts & 30 \\
\hline Mobile Vendor & 30 \\
\hline Market Vendor & 30 \\
\hline Sari-Sari Store & 30 \\
\hline Total & $\mathbf{1 8 0}$ \\
\hline
\end{tabular}

\subsection{Data Gathering Instruments}

The study adopted the instrument used by Navarra [13] to elicit data on solid waste management practices of the respondents. The questionnaire consists of three sections, namely: Types of Solid Waste Generated, Solid Waste Storage Practices and Solid Waste Management Disposal Practices. 


\subsection{Statistical Analysis}

After data gathering, the data were tabulated and analyzed. Frequency and percent statistical tool was utilized in this study.

Frequency count. The frequency count was used to find out the number of the responses to each item in the questionnaire and also the number of respondents in each category of variables in the study.

Percentage Frequency count and the percentage with reference to the majority criterion were used to describe the sources of solid waste, types of solid waste generated and solid waste management practice

\section{RESULT AND DISCUSSION}

Table 2 shows the types of solid waste generated by food service establishments. Results showed that food wastes were the main source of biodegradable wastes generated followed by paper and plant wastes. Among the food establishments, mobile vendor and food carts have the highest percentage of food waste generated with $57.14 \%$ and $52.63 \%$ respectively.

In addition, plastics topped among the non-biodegredable wastes generated by each food service establishments with $48.39 \%$ for market vendor, $43.86 \%$ for food carts, $37.88 \%$ for sari-sari store, $30.00 \%$ for bakery and $19.74 \%$ for eatery. Other wastes include used frying oil, sacks and cheesecloth.

In the study conducted by Premakumara [14], the average composition the household waste that was measured by weight are as follows: $40 \%$ are organic wastes, $17 \%$ plastics, $15 \%$ paper, $3 \%$ metal and $25 \%$ other wastes. The organic wastes fractions include food remains, kitchen wastes, and gardening-waste like leaves and small portion of soil which makes relatively large contribution to the total weight of wastes. Plastic fraction consists mostly of packaging materials which includes plastic bags.

Table 2. Types of Solid Waste Generated by the Respondents

\begin{tabular}{|c|c|c|c|c|c|c|c|c|c|c|c|c|}
\hline \multirow{2}{*}{$\begin{array}{c}\text { A. Biodegradable } \\
\text { Waste }\end{array}$} & \multicolumn{2}{|c|}{ Bakery } & \multicolumn{2}{|c|}{ Eatery } & \multicolumn{2}{|c|}{ Food Carts } & \multicolumn{2}{|c|}{$\begin{array}{l}\text { Mobile } \\
\text { Vendor }\end{array}$} & \multicolumn{2}{|c|}{$\begin{array}{l}\text { Market } \\
\text { Vendor }\end{array}$} & \multicolumn{2}{|c|}{$\begin{array}{l}\text { Sari-Sari } \\
\text { Store }\end{array}$} \\
\hline & f & $\%$ & f & $\%$ & $\mathbf{f}$ & $\%$ & $\mathbf{f}$ & $\%$ & $\mathbf{f}$ & $\%$ & $\mathbf{f}$ & $\%$ \\
\hline 1. Animal Waste & & & 4 & 5.26 & & & & & 6 & 9.68 & & \\
\hline 2. Food Waste & 15 & 37.50 & 30 & 39.47 & 30 & 52.63 & 28 & 57.14 & 5 & 8.06 & 2 & 3.03 \\
\hline 3. Paper & 3 & 7.50 & 1 & 1.32 & & & 2 & 4.08 & 5 & 8.06 & 12 & 18.18 \\
\hline 4. Plant Waste & & & 12 & 15.79 & & & & & 12 & 19.35 & & \\
\hline $\begin{array}{l}\text { B. Non- } \\
\text { Biodegradable } \\
\text { Waste }\end{array}$ & & & & & & & & & & & & \\
\hline 5. Glass/Bottles & 5 & 12.50 & 12 & 15.79 & & & & & 4 & 6.45 & 22 & 33.33 \\
\hline 6. Plastics & 12 & 30.00 & 15 & 19.74 & 25 & 43.86 & 12 & 24.49 & 30 & 48.39 & 25 & 37.88 \\
\hline 7. Tin Cans & 2 & 5.00 & 2 & 2.63 & & & 2 & 4.08 & & & 5 & 7.58 \\
\hline 8. Others & 3 & 7.50 & & & 2 & 3.51 & 5 & 10.20 & & & & \\
\hline Total & 40 & 100 & 76 & 100 & 57 & 100 & 49 & 100 & 62 & 100 & 66 & 100 \\
\hline
\end{tabular}

- Multiple responses

Table 3 shows the solid waste disposal practices among food service establishments. Mobile vendors topped among the food service establishments that used plastic bags for solid waste storage with $100 \%$ followed by food carts with $93.33 \%$. Fifty percent of bakery and $36.67 \%$ of market vendors utilized the open containers for storage and $63.33 \%$ of eatery, $50 \%$ of sari-sari stores, $36.67 \%$ of bakery used the closed containers for solid wastes generated. Other means include open pit in the backyard.

Table 3. Solid Waste Storage Practices among Respondents

\begin{tabular}{|c|c|c|c|c|c|c|c|c|c|c|c|c|}
\hline \multirow{2}{*}{$\begin{array}{l}\text { Solid Waste Storage } \\
\text { Practices }\end{array}$} & \multicolumn{2}{|c|}{ Bakery } & \multicolumn{2}{|c|}{ Eatery } & \multicolumn{2}{|c|}{$\begin{array}{l}\text { Food } \\
\text { Carts }\end{array}$} & \multicolumn{2}{|c|}{$\begin{array}{l}\text { Mobile } \\
\text { Vendor }\end{array}$} & \multicolumn{2}{|c|}{$\begin{array}{l}\text { Market } \\
\text { Vendor }\end{array}$} & \multicolumn{2}{|c|}{$\begin{array}{l}\text { Sari-Sari } \\
\text { Store }\end{array}$} \\
\hline & $\mathbf{f}$ & $\%$ & $\mathbf{f}$ & $\%$ & $\mathbf{f}$ & $\%$ & $\mathbf{f}$ & $\%$ & f & $\%$ & f & $\%$ \\
\hline Closed Container & 11 & 36.67 & 19 & 63.33 & & & & & 5 & 16.67 & 15 & 50.00 \\
\hline Open Container & 15 & 50.00 & 5 & 16.67 & 2 & 6.67 & & & 11 & 36.67 & 6 & 20.00 \\
\hline Plastic Bag & 3 & 10.00 & 6 & 20.00 & 28 & 93.33 & 30 & 100 & 14 & 46.67 & 8 & 26.67 \\
\hline Others: & 1 & 3.33 & & & & & & & & & 1 & 3.33 \\
\hline Total & 30 & 100 & 30 & 100 & 30 & 100 & 30 & 100 & 30 & 100 & 30 & 100 \\
\hline
\end{tabular}


Table 4 shows the solid waste management disposal practices among food establishment. Result depicted that most of the food service establishments depend on the City government for their solid waste disposal. Solid waste generators dumped their waste in the designated areas for collection. Two percent of eatery and sari-sari stores sell scrap materials to junkshop and $3.33 \%$ of the respondents practiced composting and buried their waste in their backyard. It is also worth noting that none of the respondents practice burning of garbage.

In contrast, $3.33 \%$ of food carts and $6.67 \%$ of mobile vendors dumped their wastes generated anywhere. In the study conducted by Bernardo [7] on the solid waste management practices of households in Metro Manila that there are respondents who dumped garbage in nondesignated pick-up points usually in the corner of the street which become the breeding ground for disease-causing organisms.

According to Sapuay [15], Ecological Solid Waste Management Act of 2000 provides the legal framework for the systematic, comprehensive and ecological solid waste management program of the Philippines, which shall ensure protection of public health and environment. It emphasizes the need to create the necessary institutional mechanisms and incentives, and imposes penalties for acts in violation of any of its provisions.

Table 4. Solid Waste Management Disposal Practices among Respondents

\begin{tabular}{|c|c|c|c|c|c|c|c|c|c|c|c|c|}
\hline \multirow{2}{*}{$\begin{array}{l}\text { Solid Waste Disposal } \\
\text { Practices }\end{array}$} & \multicolumn{2}{|c|}{ Bakery } & \multicolumn{2}{|c|}{ Eatery } & \multicolumn{2}{|c|}{ Food Carts } & \multicolumn{2}{|c|}{$\begin{array}{l}\text { Mobile } \\
\text { Vendor }\end{array}$} & \multicolumn{2}{|c|}{$\begin{array}{l}\text { Market } \\
\text { Vendor }\end{array}$} & \multicolumn{2}{|c|}{$\begin{array}{l}\text { Sari-Sari } \\
\text { Store }\end{array}$} \\
\hline & $\mathbf{f}$ & $\%$ & f & $\%$ & f & $\%$ & $\mathbf{f}$ & $\%$ & $\mathbf{f}$ & $\%$ & $\mathbf{f}$ & $\%$ \\
\hline \multicolumn{13}{|l|}{ Burning } \\
\hline $\begin{array}{l}\text { Burying in the } \\
\text { Backyard }\end{array}$ & 1 & 3.33 & & & & & & & & & 1 & 3.33 \\
\hline Composting & & & & & & & & & 1 & 3.33 & & \\
\hline $\begin{array}{l}\text { Depending on City } \\
\text { Waste Collector }\end{array}$ & 29 & 96.67 & 28 & 93.33 & 29 & 96.67 & 28 & 93.33 & 29 & 96.67 & 27 & 90.00 \\
\hline Dumping Anywhere & & & & & 1 & 3.33 & 2 & 6.67 & & & & \\
\hline \multicolumn{13}{|l|}{ Recycling } \\
\hline \multicolumn{13}{|l|}{ Reducing } \\
\hline \multicolumn{13}{|l|}{ Reusing } \\
\hline \multicolumn{13}{|l|}{ Recover } \\
\hline Selling to Junkshop & & & 2 & 6.67 & & & & & & & 2 & 6.67 \\
\hline \multicolumn{13}{|l|}{ Others: } \\
\hline Total & 30 & 100 & 30 & 100 & 30 & 100 & 30 & 100 & 30 & 100 & 30 & 100 \\
\hline
\end{tabular}

\section{CONCLUSION}

Based from the result of the study, the following conclusions were drawn:

1. Food service establishments generated biodegradable and non-biodegradable solid wastes. Food waste topped among the biodegradable waste followed by paper and plant wastes while plastics are among the nonbiodegradable waste generated by the solid waste generators.

2. Food service establishments stored their solid wastes using plastic bags. Closed and open containers were also utilized.

3. The food service establishments were dependent to the City government for their solid waste disposal. Solid waste generators dumped their waste in the designated areas for collection. It is worth noting that none of the respondents practice burning of garbage but few are dumping their garbage anywhere. None of the respondents practiced solid waste segregation and 3Rs. Proof established that Republic Act 9003 or Solid Waste management Act of 200 is not fully implement in the City of Talisay.

\section{REFERENCES}

[1] Aquino, AP., Deriquito, JAP., Festejo, MA. (2013). Ecological solid waste management act: environmental protection through proper solid waste practice. Retrieved August 22, 2015 from http://ap.fftc.agnet.org/ap_db.php?id=153\&print=1

[2] Atienza, V. (2011). Review of the waste management in the Philippines: initiatives to promote solid waste segregation and recycling through good governance. Retrieved July 30, 2015 from http://www.ide.go.jp/Japanese/Publish/Download/Repo rt/2010/pdf/2010_431_05.pdf

[3] Bajet, MA., et.al. (2012). Solid waste management practices in Vigan City, Ilocos Sur, Philippines. IAMURE International Journal of Ecology and Conservation, Vol 3 No.1. Retrieved August 20, 2015 from

http://iamure.com/publication/index.php/ijec/article/vie w/326

[4] Beede, DN., \& Bloom, DE. (1995). The economics of municipal solid waste. The World Bank Research Observer. -- Vol. 10, no. 2 (August 1995), pp. 113-50. 
Retrieved August 13, 2015 from http://documents.worldbank.org/curated/en/1995/08/17 703177/economics-municipal-solid-waste

[5] Begum, Z. (). Solid waste management. Dissemination paper-19. India: Madras School of Economics. Retrieved November 22, 2015 from http://coe.mse.ac.in/dp/Dissemination\%20Paper $\% 2019 \% 20$.pdf.

[6] Bennagen, MEC., Nepomuceno, G., \& Cobar, R. (2002). Solid waste segregation and recycling in Metro Manila: households attitudes and behaviour. Economy and Environment Program for Southeast Asia (EEPSA), Singapore. Retrieved November 11, 2015 from https://idl-

bnc.idrc.ca/dspace/bitstream/10625/32393/3/118095.pdf

[7] Bernardo, EC. (2008). Solid waste management practices of household in Manila, Philippines. Annals of New York Academy of Sciences. Retrieved October 15, 2015 from http://onlinelibrary.wiley.com/doi/10.1196/annals.1454. 016/abstract

[8] Bravo, MR. (2006). An evaluation of the solid waste management (swm) system in marikina city, philippines with comparisons in tsukuba city, japan. Presented during the symposium on infrastructures development and the environment. 7-8 December 2006, SEAMEOINNOTECH, University of the Philippines, Diliman, Quezon City.

[9] Cruz, T. (1995). Ecological waste management, WO Magazines. Philippines: Creative Business, Inc.

[10] El-Hawi, MK. (2004). Towards and environmentally sound sustainable solid waste disposal strategy: the Gaza Strip case. Retrieved October 12, 2015 from http://usir.salford.ac.uk/14854/1/401979.pdf

[11] Gador, RV. (2009). Solid waste management practices of Davao City. Southeastern Philippines Journal of Research and Development, Vol. 18 No. 2. Retrieved October 22, 2015 from http://ejournals.ph/index.php?journal=cjkdshafjsdbcvn mxbAJSDNJKSNCSDKA\&page=article\&op=viewArti cle\&path $\% 5 \mathrm{~B} \% 5 \mathrm{D}=3573$

[12]Karija, MK., Shihua, QI., Yukaw, YS. (2013). The impact of poor municipal solid waste management practices and sanitation status on water quality and public health in cities of the least developed countries: the case of Juba, South Sudan. International Journal of Applied Science and Technology, Volume 3, No. 4. Retrieved August 15, 2015 from http://www.ijastnet.com/journals/Vol_3_No_4_April_2 013/11.pdf

[13]Navarra, HU., Acanto., RB., \& Bajon, JP. (2010). Solid waste management practices in Ibajay, Aklan. Unpublished Research. Aklan State University - Ibajay Campus, Ibajay, Aklan.

[14]Premakumara, DGJ. (2011). Survey of household solid waste generation and public awareness on waste separation and composting practices in Cebu City. Institute for Global Environmental Strategies. Kitakyushu Urban Centre Japan. Retrieved November 11, 2015 from http://pub.iges.or.jp/modules/envirolib/upload/3585/atta ch/Cebu.Survey.Report[final].pdf
[15]Sapuay, GP. (2014). Ecological solid waste management act of 2000 (RA 9003): a major step to better solid waste management in the Philippines. Retrieved November 12, 2015 from http://www.researchgate.net/publication/237584037

[16] Schübeler, P. (1996). Conceptual framework for municipal solid waste management in low-income countries. World Bank Urban Management and Infrastructure. Retrieved November 11, 2015 from http://www.worldbank.org/urban/solid_wm/erm/CWG $\% 20$ folder/conceptualframework.pdf

[17] Shanklin, CW., Petrillose, MJ. \& Pettay, A. (1991). Solid waste management practices in selected hotel chains and individual properties. USA: Journal of Hospitality and Tourism Research, Vol. 15, No. 1 . Retrieved August 12, 2015 from http://jht.sagepub.com/content/15/1/59

[18]Srivinas, H. (2015). A policy and programme matrix. Retrieved October 22, 2015 from http://www.gdrc.org/uem/waste/swm-matrix.html

[19] Torres, EO. (2009). Solid waste management in the philippines. Retrieved September 15, 2015 from http://www.fukuoka.unhabitat.org/kcap/activities/egm/2 009/pdf/torres_en.pdf

[20] Wangatia, MV. (2014). Socioeconomics implications of solid waste management practices on participating household in Kenya. Retrieved August 15, 2015 from http://elearning.jkuat.ac.ke/journals/ojs/index.php/jscp/a rticle/viewFile/1083/887.

[20] Environmental Management Bureau. Managing our solid waste: an overview of the ecological solid waste management act. Retrieved August 15, 2015 from http://emb.gov.ph/eeid/ESWM.htm

[21] Republic Act 9003. An act providing for an ecological solid waste management program, creating the necessary institutional mechanisms and incentives. Declaring certain acts prohibited and providing penalties, appropriating funds therefore and other purposes. Retrieved September 15, 2015 from http://www.lawphil.net/statutes/repacts/ra2001/ra_9003 _2001.html

[22] Selection, Design and Implementation of Economic Instruments in the Kenyan Solid Waste Management Sector, Nairobi, Kenya. Retrieved October 15, 2015 from http://www.unep.org/PDF/Kenya_waste_mngnt_sector/ waste_mngnt_final_draft-23Feb.pdf

[23] Solid wastes. Harmful effects. Retrieved August 25, 2015 from http://www.healthepic.com/explorebody/healthhazards/Solid-Wastes-Hazards.htm

\section{BIOGRAPHY}

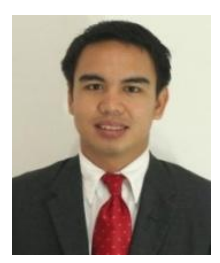

The author is a science faculty of the School of Arts and Sciences, Carlos Hilado Memorial State College, Talisay City, Negros Occidental, Philippines. His researches are focused on environment and natural product chemistry. 